\title{
Phenylalanyl-tRNA synthetase editing defects result in efficient mistranslation of phenylalanine codons as tyrosine
}

\author{
JIQIANG LING, ${ }^{1}$ SRUJANA S. YADAVALLI, ${ }^{2}$ and MICHAEL IBBA ${ }^{1,2}$ \\ ${ }^{1}$ Ohio State Biochemistry Program, The Ohio State University, Columbus, Ohio 43210, USA \\ ${ }^{2}$ Department of Microbiology and Ohio State RNA Group, The Ohio State University, Columbus, Ohio 43210, USA
}

\begin{abstract}
Translational quality control is monitored at several steps, including substrate selection by aminoacyl-tRNA synthetases (aaRSs), and discrimination of aminoacyl-tRNAs by elongation factor Tu (EF-Tu) and the ribosome. Phenylalanyl-tRNA synthetase (PheRS) misactivates Tyr but is able to correct the mistake using a proofreading activity named editing. Previously we found that overproduction of editing-defective PheRS resulted in Tyr incorporation at Phe-encoded positions in vivo, although the misreading efficiency could not be estimated. This raised the question as to whether or not EF-Tu and the ribosome provide further proofreading mechanisms to prevent mistranslation of Phe codons by Tyr. Here we show that, after evading editing by PheRS, Tyr-tRNA ${ }^{\text {Phe }}$ is recognized by EF-Tu as efficiently as the cognate Phe-tRNA ${ }^{\text {Phe }}$. Kinetic decoding studies using full-length Tyr-tRNA $^{\text {Phe }}$ and Phe-tRNA ${ }^{\text {Phe }}$, as well as a poly $(U)$-directed polyTyr/polyPhe synthesis assay, indicate that the ribosome lacks discrimination between Tyr-tRNA $^{\text {Phe }}$ and Phe-tRNA ${ }^{\text {Phe }}$. Taken together, these data suggest that PheRS editing is the major proofreading step that prevents infiltration of Tyr into Phe codons during translation.
\end{abstract}

Keywords: editing; proofreading; protein synthesis; quality control; translation; tRNA

\section{INTRODUCTION}

As a central process of biology, translation utilizes a conserved machinery throughout the three domains of life. Passage of genetic information from mRNA to protein can be separated into several steps, with transfer RNAs (tRNA) playing an adaptor role to pair amino acids with their cognate codons during translation. Amino acids are first attached to their cognate tRNAs by aminoacyl-tRNA synthetases (aaRSs); the resulting aminoacyl-tRNAs (aatRNAs) are subsequently delivered by elongation factors (EF-Tu in bacteria and EF- $1 \alpha$ in archaea and eukarya) to ribosomes, where codon-anticodon recognition programs incorporation of amino acids into the elongating peptides. It is critical for organisms to maintain translational accuracy, as several studies have suggested that increased translational error rates can slow growth in bacteria (Nangle et al. 2002; Roy et al. 2004; Bacher et al. 2005) and cause neurodegeneration in mammals (Lee et al. 2006). To ensure quality control during translation the cell utilizes

Reprint requests to: Michael Ibba, Department of Microbiology, The Ohio State University, 484 West 12th Avenue, Columbus, OH 43210-1292, USA; e-mail: ibba.1@osu.edu; fax: 614-292-8120.

Article published online ahead of print. Article and publication date are at http://www.rnajournal.org/cgi/doi/10.1261/rna.684107. several strategies, including aaRS editing, EF-Tu discrimination, and ribosomal selection (Ibba and Söll 1999; Dale and Uhlenbeck 2005a).

aaRSs usually selectively activate their cognate amino acids during aminoacylation. However, errors in aminoacylation can occur when synthetases encounter noncognate amino acids or analogs that are structurally similar to their cognate substrates. For example, phenylalanyl-tRNA synthetase (PheRS) misactivates tyrosine at a rate significantly higher than the overall translational error rate (Roy et al. 2005). To maintain accuracy during translation, PheRS uses an editing domain that hydrolyzes misacylated tRNA $^{\text {Phe }}$ (Lin et al. 1984; Roy et al. 2004, 2005). Similar activities are found in many other aaRSs (Nureki et al. 1998; Silvian et al. 1999; Beuning and Musier-Forsyth 2000; Dock-Bregeon et al. 2000, 2004; Fukai et al. 2000; Ahel et al. 2003; Beebe et al. 2003, 2004; Lincecum et al. 2003; Wong et al. 2003; Korencic et al. 2004), suggesting that editing is widely used to proofread mistakes made in aminoacylation. Such editing activities are critical for the cell. It has been reported that a partial loss of alanyl-tRNA synthetase (AlaRS) editing function in mice results in protein misfolding and neurodegeneration (Lee et al. 2006), demonstrating the significance of maintaining a full editing activity. 
EF-Tu was long considered to bind all aa-tRNAs with roughly equal efficiencies, the only exceptions being fMettRNA $^{\text {fMet, }}$ Ser/Sec-tRNA ${ }^{\text {sec }}$, Glu-tRNA ${ }^{\text {Gln }}$, and AsptRNA $^{\text {Asn }}$ (Stanzel et al. 1994; Becker and Kern 1998; Dale and Uhlenbeck 2005a; Ambrogelly et al. 2007; Roy et al. 2007). The weak affinity of EF-Tu for Glu-tRNA ${ }^{\text {Gln }}$ and Asp-tRNA ${ }^{\text {Asn }}$ prevents genetic ambiguity that would result from misincorporating Glu and Asp at Gln and Asn codons, respectively, while fMet-tRNA ${ }^{\text {fMet }}$ and Sec-tRNA ${ }^{\text {Sec }}$ instead bind specialized translation factors (Ambrogelly et al. 2007). Recently, Uhlenbeck and colleagues found that EF-Tu displays selectivity for both the amino acid and the tRNA body (LaRiviere et al. 2001; Asahara and Uhlenbeck 2002, 2005; Dale et al. 2004). It was proposed that, since EF-Tu binds amino acids with various affinities, their corresponding tRNAs have evolved to compensate for the differences in affinity thermodynamically, so that EF-Tu binds all cognate aa-tRNAs uniformly (Dale and Uhlenbeck 2005a). In contrast to cognate aa-tRNAs, EF-Tu binds their noncognate counterparts with a wide range of affinities, which may lead to reduced incorporation efficiencies for some mischarged amino acids.

The last step at which translational fidelity can be monitored is ribosomal decoding. Proper matching of codons and anticodons is a prerequisite for efficient decoding, and the ribosome utilizes both thermodynamic and kinetic discrimination mechanisms to reject aa-tRNAs with near-cognate or noncognate anticodons (Gromadski and Rodnina 2004a; Cochella and Green 2005). It is less clear, however, whether ribosomes are able to discriminate against misacylated tRNAs with cognate codons. Misacylated tRNAs have been shown to be utilized in translation of peptides in vitro and in vivo (Chapeville et al. 1962; Döring et al. 2001; Nangle et al. 2002; Bacher et al. 2005; Lee et al. 2006; Wang et al. 2006; Xie and Schultz 2006), although the decoding rates for these species are unknown. Several lines of evidence suggest that the ribosome may discriminate the side chains of amino acids. In a study by Bhuta and colleagues several amino acids were ligated to the $\mathrm{C}-\mathrm{A}$ dinucleotide. The resulting aminoacyl-dinucleotides (C-Aaa) displayed a broad range of affinities for the ribosomal $\mathrm{A}$ site in a peptidyl transferase assay (Bhuta et al. 1981). Translation inhibition experiments using various puromycin derivatives also indicated that the ribosomal A site specifically recognizes the amino acid side chains of aa-tRNAs (Starck et al. 2003). Conversely, nonenzymatic binding studies using full-length aa-tRNAs showed that misacylated and correctly acylated tRNAs bind to the ribosomal A site with similar affinities (Fahlman et al. 2004; Dale and Uhlenbeck 2005b). To provide some insights into the discrepancy, we investigated the effect on decoding kinetics of full-length misacylated tRNAs, as part of a broader study of the quality control mechanisms that prevent misincorporation of Tyr at Phe codons. We found that EF-Tu efficiently recognizes Tyr-tRNA ${ }^{\text {Phe }}$ syn- thesized by an editing-defective PheRS, and that the ribosome does not discriminate Tyr-tRNA ${ }^{\text {Phe }}$ from the cognate Phe-tRNA ${ }^{\text {Phe }}$, as revealed by a fast-kinetic decoding experiment and poly(U)-directed polyPhe or polyTyr synthesis assays. Together, our data suggest that PheRS editing is the major proofreading step that prevents infiltration of Tyr into Phe codons during translation.

\section{RESULTS AND DISCUSSION}

\section{Misacylation of tRNA $^{\text {Phe }}$ by editing-defective PheRSs}

Previously we have shown that Escherichia coli PheRS possesses an editing activity against Tyr (Roy et al. 2004). PheRS editing site residues are mainly involved in substrate binding, and mutations of the conserved residues resulted in, at best, only a few fold decrease in editing (Ling et al. 2007). A question that arose is why the editing site residues are so conserved even though they do not contribute significantly to activity. Traditionally, editing experiments are performed in the absence of nonsynthetase cellular factors such as EF-Tu. Nevertheless, it has been shown that EF-Tu significantly increases the steady-state levels of cognate and misacylated tRNAs (Wolfson and Uhlenbeck 2002; Lee et al. 2006), which prompted us to further investigate the mischarging activities of PheRS variants in the presence and absence of EF-Tu. The wild-type (WT) PheRS did not produce accumulated Tyr-tRNA ${ }^{\text {Phe }}$ irrespective of EF-Tu addition (Fig. 1). As the WT and editing defective PheRSs display similar aminoacylation activities (Ling et al. 2007), it is likely that the WT PheRS hydrolyzes Tyr-tRNA $^{\text {Phe }}$ before it is trapped by EF-Tu. In contrast, editing-defective PheRS variants displayed significantly

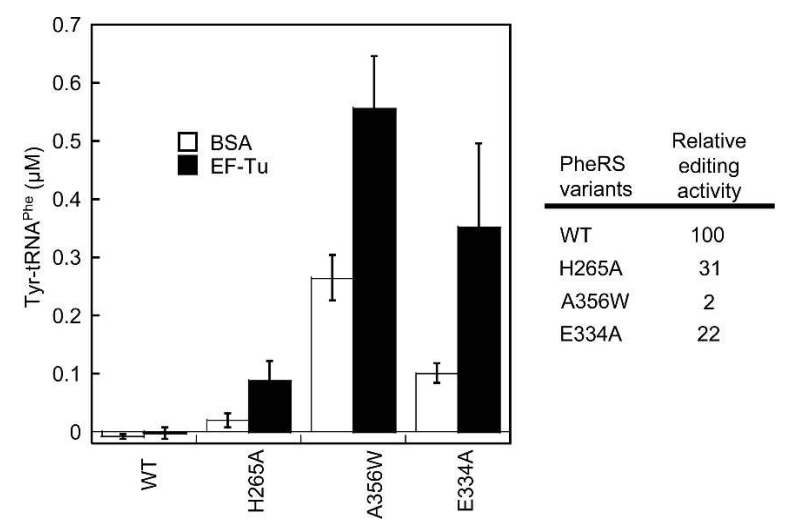

FIGURE 1. Tyrosylation of E. coli tRNA ${ }^{\text {Phe }}(5 \mu \mathrm{M})$ by PheRS variants ( $0.5 \mu \mathrm{M}$ each) in the presence (filled bars) and absence (open bars) of EF-Tu $(5 \mu \mathrm{M})$. The Y-axis represents the end levels of Tyr-tRNA ${ }^{\text {Phe }}$ synthesized after $6 \mathrm{~min}$. PheRS variants contain either a wild-type editing site (WT) or mutations in the $\beta$ subunit that reduce the editing activity (Ling et al. 2007). Relative post-transfer editing activities determined previously are shown in the figure. Data sets are the average of three independent experiments. 
increased tyrosylation levels in the presence of EF-Tu, likely through EF-Tu protection of synthesized Tyr-tRNA ${ }^{\text {Phe }}$ from hydrolysis. The $\beta \mathrm{H} 265 \mathrm{~A}$ variant, which has a threefold reduced post-transfer editing activity, misacylated tRNA $^{\text {Phe }}$ very weakly in the absence of EF-Tu. Addition

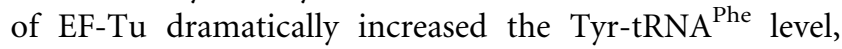
suggesting a critical role of $\beta \mathrm{H} 265$ for editing in vivo. It appears that the PheRS editing site has evolved to maintain a minimal editing efficiency while preventing "misediting" of the cognate Phe (Ling et al. 2007). Current views on the roles of aaRS editing site residues may need to be revisited in the context of in vivo conditions, as it now seems likely that aaRS editing sites have been fine-tuned to avoid uptake of misacylated tRNAs by elongation factors. This is consistent with the observation that a trans-editing factor, YbaK, associates with ProRS to compete with EF-Tu for mischarged Cys-tRNA ${ }^{\text {Pro }}$ (An and Musier-Forsyth 2005).

\section{EF-Tu efficiently recognizes Tyr-tRNA ${ }^{\text {Phe }}$}

EF-Tu increased the tyrosylation level of $\mathrm{tRNA}^{\text {Phe }}$ by PheRS, suggesting that Tyr-tRNA ${ }^{\text {Phe }}$ might be protected by EF-Tu. To directly address this possibility, we tested the dissociation rates of Tyr-tRNA ${ }^{\text {Phe }}$ and Phe-tRNA ${ }^{\text {Phe }}$ from E. coli EF-Tu using an RNase A protection assay as previously described (LaRiviere et al. 2001; Asahara and Uhlenbeck 2002). The $k_{\text {off }}$ rates of Tyr-tRNA ${ }^{\text {Phe }}$ and PhetRNA ${ }^{\text {Phe }}$ were very similar at $2^{\circ} \mathrm{C}$ (Fig. 2A), comparable to values for cognate aa-tRNAs determined using Thermus thermophilus EF-Tu (LaRiviere et al. 2001; Dale et al. 2004). The $k_{\text {off }}$ values of both Tyr-tRNA ${ }^{\text {Phe }}$ and Phe-tRNA ${ }^{\text {Phe }}$ were increased by $\sim 30$-fold when the reaction temperature was raised to $37^{\circ} \mathrm{C}$ (Fig. $2 \mathrm{~B}$ ), consistent with previous observations (Vorstenbosch et al. 2000). It has been predicted that some misacylated tRNAs bind EF-Tu either too tightly or too weakly to allow efficient delivery to the ribosome (LaRiviere et al. 2001; Asahara and Uhlenbeck 2005). However, many noncognate aa-tRNAs bind to EF-Tu with affinities similar to their cognate counterparts (Asahara and Uhlenbeck 2005). The data collected here show that E. coli EF-Tu does not discriminate Tyr-tRNA ${ }^{\text {Phe }}$ from PhetRNA $^{\text {Phe }}$. A cocrystal structure of EF-Tu complexed with Phe-tRNA ${ }^{\text {Phe }}$ and a GTP analog revealed that the Phe side chain is stacked by a His residue (Nissen et al. 1995). Thus, it is likely that Tyr and Phe interact with the amino acid binding site of EF-Tu in the same manner, and that the presence of the $p$-hydroxyl group in Tyr does not hinder EF-Tu binding.

\section{The ribosome does not discriminate Tyr-tRNA ${ }^{\text {Phe }}$ from Phe-tRNA ${ }^{\text {Phe }}$}

In a previously established in vivo assay using an amber suppressor tRNA ${ }_{\text {CUA }}^{\text {Phe }}$, we observed that Tyr was misincorparated into UAG amber codons upon expression of an
A

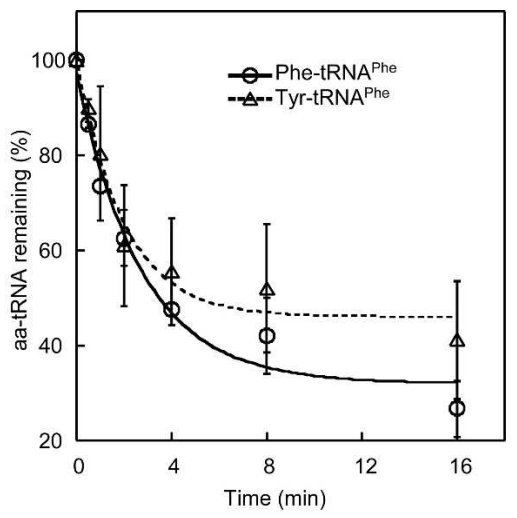

B

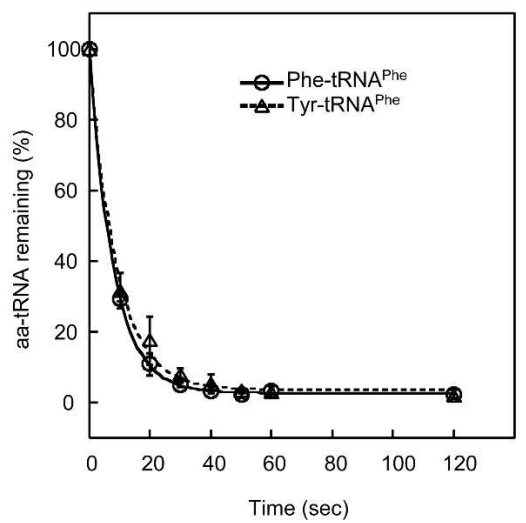

FIGURE 2. Determination of $k_{\text {off }}$ rates of Phe- and Tyr-tRNA ${ }^{\text {Phe }}$ from EF-Tu. The dissociation rates are $(A) 0.21 \pm 0.06 \mathrm{~min}^{-1}$ (PhetRNA $\left.^{\text {Phe }}\right), 0.29 \pm 0.19 \mathrm{~min}^{-1}\left(\right.$ Tyr-tRNA $\left.{ }^{\text {Phe }}\right)$ at $2^{\circ} \mathrm{C}$ and $(B) 7.7 \pm 0.2$ $\min ^{-1}$ (Phe-tRNA ${ }^{\text {Phe }}$ ) and $6.8 \pm 1.2 \mathrm{~min}^{-1}\left(\right.$ Tyr-tRNA ${ }^{\text {Phe }}$ ) at $37^{\circ} \mathrm{C}$. Data sets are the average of three independent experiments.

editing-defective PheRS (Roy et al. 2004), suggesting that the ribosome is able to use Tyr-tRNA ${ }_{\text {CUA }}^{\mathrm{Phe}}$ as a substrate. What remained unknown, however, was how efficiently the ribosome recognizes the mischarged Tyr-tRNA ${ }^{\text {Phe }}$. To test decoding efficiency, we prepared 70S ribosomal initiation complexes with formyl- $\left[{ }^{35} \mathrm{~S}\right]-\mathrm{Met}_{-\mathrm{RNA}}{ }^{\mathrm{fMet}}$ in the $\mathrm{P}$ site and codon UUU, UUC, or CUU in the A site. Next, EF-Tu bound Tyr-tRNA ${ }^{\text {Phe }}$ or Phe-tRNA ${ }^{\text {Phe }}$ was added to the initiation complexes in a quenched-flow apparatus and the formation of dipeptides monitored. Fully modified native tRNA $^{\text {Phe }}$ was used to exclude potential impacts of modifications on decoding. The near-cognate CUU codon was decoded very poorly by Phe-tRNA ${ }^{\text {Phe }}$, while Tyr-tRNA ${ }^{\text {Phe }}$ read UUU and UUC Phe codons as efficiently as PhetRNA $^{\text {Phe }}$ (Fig. 3A; Table 1), suggesting that the ribosomal A site recognizes Tyr-tRNA ${ }^{\text {Phe }}$ and Phe-tRNA ${ }^{\text {Phe }}$ equally well. To further test if the ribosome might discriminate TyrtRNA $^{\text {Phe }}$ at other steps in elongation, we performed poly(U)-directed polyTyr and polyPhe synthesis. The synthesis rates of polyTyr and polyPhe were almost identical (Fig. 3B), confirming that the ribosome lacks discrimination between Tyr and Phe side chains in the 
A

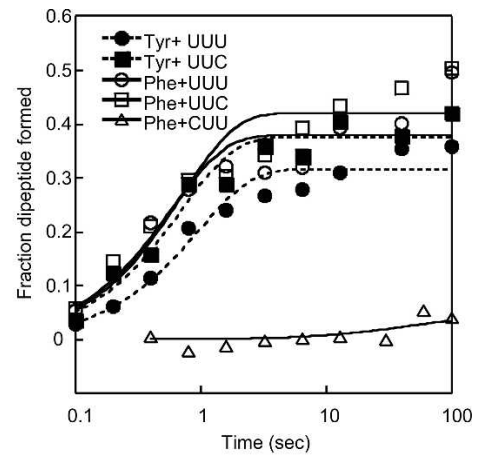

B

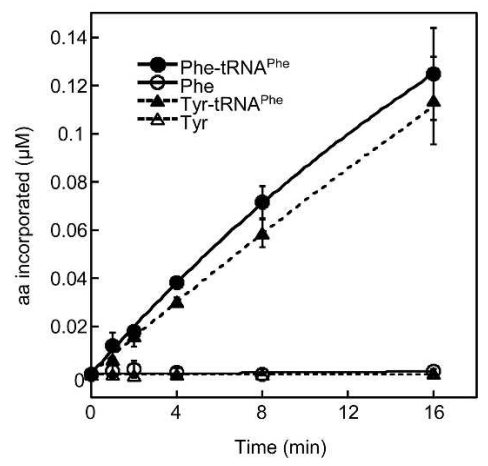

FIGURE 3. Decoding of Phe codons by Tyr-tRNA ${ }^{\text {Phe }}$ and PhetRNA $^{\text {Phe }}$. (A) fMet-Tyr and fMet-Phe dipeptide formation upon decoding of cognate (UUU and UUC) and near-cognate (CUU) Phe codons. Reactions contain $100 \mathrm{nM}$ ribosomal initiation complex and $50 \mathrm{nM}$ aa-tRNA ${ }^{\text {Phe }}$. The $\mathrm{Y}$-axis shows the fraction of aa-tRNA ${ }^{\text {Phe }}$ converted to dipeptide. Solid symbols, Tyr-tRNA ${ }^{\text {Phe }}$; open symbols, Phe-tRNA ${ }^{\text {Phe }}$. (B) Poly $(U)$-directed polyPhe and polyTyr synthesis. The reaction mixture contains $200 \mathrm{nM} 70 \mathrm{~S}$ ribosomes, $1 \mu \mathrm{M}$ EF-G, $5 \mu \mathrm{M}$ EF-Tu, $0.3 \mu \mathrm{g} / \mu \mathrm{L}$ poly $(U)$ mRNA, and $1 \mu \mathrm{M}\left[{ }^{14} \mathrm{C}\right]$ PhetRNA $^{\text {Phe }}$ or $\left[{ }^{3} \mathrm{H}\right]$ Tyr-tRNA ${ }^{\text {Phe }}$ synthesized with native E. coli tRNA ${ }^{\text {Phe }}$. As controls, $1 \mu \mathrm{M}\left[{ }^{14} \mathrm{C}\right]$ Phe or $\left[{ }^{3} \mathrm{H}\right]$ Tyr are added instead of $\left[{ }^{14} \mathrm{C}\right]$ Phe-tRNA $^{\text {Phe }}$ or $\left[{ }^{3} \mathrm{H}\right]$ Tyr-tRNA ${ }^{\text {Phe }}$. Data sets are the average of three independent experiments.

context of tRNA ${ }^{\text {Phe }}$. Previous studies showed that the ribosomal A site has different affinities for various aminoacyl-dinucleotide and puromycin derivatives (Bhuta et al. 1981; Starck et al. 2003), while nonenzymatic binding experiments suggested that the A site binds all tested misacylated tRNAs and cognate aa-tRNAs uniformly (Fahlman et al. 2004; Dale and Uhlenbeck 2005b). Upon codon-anticodon recognition, the ribosome undergoes a series of conformational changes (Pape et al. 1998, 1999, 2000; Ogle et al. 2002; Blanchard et al. 2004; Gromadski and Rodnina 2004a,b; Cochella and Green 2005). It is possible that, in nonenzymatic binding experiments, some rate-limiting induced-fit steps cannot be detected (Dale and Uhlenbeck 2005a). Alternatively, the aminoacyl-dinucleotide and puromycin derivatives may not bind to the ribosomal A site exactly as full-length aa-tRNAs do, as it has been suggested that the ribosomal active site adopts different conformations upon binding of puromycin derivatives or full-length aa-tRNAs (Youngman et al. 2004; Schmeing et al. 2005). The kinetic experiments demonstrate that Tyr-tRNA $^{\text {Phe }}$ is not discriminated by the ribosome; whether or not this conclusion is valid for other misacylated tRNAs now requires further systematic kinetic analyses.

\section{The editing activity of PheRS is essential for translational quality control}

Our data demonstrated that, once Tyr-tRNA ${ }^{\text {Phe }}$ evades editing by PheRS, incorporation of Tyr at Phe codons is inevitable. EF-Tu and the ribosome, which are downstream from aa-tRNA synthesis, do not provide further proofreading mechanisms to avoid Tyr misincorporation. This is distinct from some naturally misacylated tRNAs, such as Glu-tRNA $^{\text {Gln }}$ and Asp-tRNA ${ }^{\text {Asn }}$, which are discriminated by EF-Tu (Stanzel et al. 1994; Becker and Kern 1998). Uhlenbeck and coworkers proposed that, since EF-Tu and possibly the ribosome display selectivity for different amino acids, their cognate tRNAs might have evolved to compensate for the binding affinities thermodynamically, so that all cognate aa-tRNAs can be translated uniformly (Dale and Uhlenbeck 2005a). Our findings support this hypothesis, as Tyr-tRNA $^{\text {Phe }}$ accumulation is normally prevented by the PheRS editing activity and as a result there is no selective pressure to drive further evolution of $\mathrm{RRNA}^{\text {Phe }}$. This hypothesis also explains why unnatural amino acids are usually efficiently incorporated into proteins in vivo, as the necessary orthogonal aaRSs do not exist in nature.

\section{MATERIALS AND METHODS}

\section{Strains, plasmids, site-directed mutagenesis, and general methods}

E. coli JM109/pKECA-Tu producing $\mathrm{His}_{6}$-tagged E. coli EF-Tu was a gift from B. Kraal (Leiden University, Leiden, The Netherlands).

TABLE 1. Kinetics of dipeptide bond formation at different mRNA A site codons using native tRNA ${ }^{\text {Phe }}$ aminoacylated with either Tyr or Phe.

\begin{tabular}{lcccrr}
\hline Aminoacyl-tRNA & Phe & Tyr-tRNA & Tyr-tRNA & Phe-tRNA & \multicolumn{2}{c}{ Phe-tRNA } & Phe-tRNA \\
\hline A site codon & UUU & UUC & UUU & UUC & CUU \\
$k_{\text {obs }}\left(\mathrm{sec}^{-1}\right.$ ) & $1.1 \pm 0.5$ & $1.4 \pm 0.1$ & $1.8 \pm 0.4$ & $1.5 \pm 0.2$ & $0.03 \pm 0.02$ \\
Final fMet-Phe fraction & $0.32 \pm 0.01$ & $0.38 \pm 0.08$ & $0.38 \pm 0.08$ & $0.42 \pm 0.16$ & $0.05 \pm 0.01$ \\
\hline
\end{tabular}


E. coli strain XL1-Blue/pQE31-FRS expressing the WT E. coli PheRS was a gift from D.A. Tirrell (California Institute of Technology). PheRS variants were previously obtained by sitedirected mutagenesis in our laboratory (Roy et al. 2004). E. coli tRNA $^{\text {Phe }}$ and mRNA transcripts were prepared using in vitro T7 RNA polymerase runoff transcription as described (Roy et al. 2004). Native E. coli $\mathrm{tRNA}^{\mathrm{Phe}}$, $\mathrm{tRNA}^{\mathrm{fMet}}$, and poly(U) were purchased from Sigma-Aldrich.

\section{Aminoacylation}

Tyrosylation experiments were performed at $37^{\circ} \mathrm{C}$ as described (Roy et al. 2004) in the presence of $0.1 \mathrm{M} \mathrm{Na-HEPES} \mathrm{pH} \mathrm{7.2,}$ $30 \mathrm{mM} \mathrm{KCl}, 10 \mathrm{mM} \mathrm{MgCl}_{2}, 2 \mathrm{mM}$ ATP, $5 \mu \mathrm{M}$ E. coli $\mathrm{tRNA}^{\text {Phe }}$ transcript, $50 \mu \mathrm{M}\left[{ }^{3} \mathrm{H}\right]$ Tyr $(464 \mathrm{cpm} / \mathrm{pmol})$, and $0.5 \mu \mathrm{M}$ PheRS, with or without $5 \mu \mathrm{M}$ E. coli EF-Tu. EF-Tu was activated in $50 \mathrm{mM}$ Tris- $\mathrm{HCl}, 1 \mathrm{mM}$ DTT, $68 \mathrm{mM} \mathrm{KCl}, 6.7 \mathrm{mM} \mathrm{MgCl}_{2}$, $2.5 \mathrm{mM}$ phosphoenolpyruvate (PEP), $0.5 \mathrm{mM}$ GTP, and $30 \mu \mathrm{g} /$ $\mathrm{mL}$ pyruvate kinase $(\mathrm{PK})$ at $37^{\circ} \mathrm{C}$ for $20 \mathrm{~min}$ before use.

\section{Determination of $\boldsymbol{k}_{\text {off }}$ values for EF-Tu}

E. coli EF-Tu was activated in $50 \mathrm{mM}$ Na-HEPES pH 7.2, $5 \mathrm{mM}$ DTT, $150 \mathrm{mM} \mathrm{NH}_{4} \mathrm{Cl}, 20 \mathrm{mM} \mathrm{MgCl}_{2}$, $3 \mathrm{mM}$ PEP, $2 \mathrm{mM}$ GTP, and $30 \mu \mathrm{g} / \mathrm{mL} \mathrm{PK}$ at $37^{\circ} \mathrm{C}$ for $20 \mathrm{~min}$. A final concentration of $0.5 \mu \mathrm{M}\left[{ }^{14} \mathrm{C}\right]$ Phe-tRNA ${ }^{\text {Phe }}$ or $\left[{ }^{3} \mathrm{H}\right]$ Tyr-tRNA ${ }^{\text {Phe }}$ were added to $10 \mu \mathrm{M}$ activated EF-Tu and incubated on ice for $5 \mathrm{~min}$. RNase A was added to the reaction mixture to a final concentration of 100 $\mu \mathrm{g} / \mathrm{mL}$ and aliquots were taken at each time point, spotted on $3 \mathrm{MM}$ discs presoaked with $5 \%$ trichloric acid (TCA), washed, dried, and scintillation counted.

\section{fMet-Phe and fMet-Tyr dipeptide formation}

$70 S$ ribosomes from E. coli strain MRE600 were prepared as described (Fredrick and Noller 2002). Decoding experiments were performed in buffer A (50 mM Tris- $\mathrm{HCl} \mathrm{pH} \mathrm{7.5,} 70 \mathrm{mM} \mathrm{NH}_{4} \mathrm{Cl}$, $30 \mathrm{mM} \mathrm{KCl}, 3.5 \mathrm{mM} \mathrm{MgCl}, 0.5 \mathrm{mM}$ spermidine, $8 \mathrm{mM}$ putrescine, and $2 \mathrm{mM} \mathrm{DTT}$ ), which mimics in vivo conditions and is highly accurate for decoding. Initiation complexes were prepared by mixing $2 \mu \mathrm{M} 70 \mathrm{~S}$ ribosomes, $4 \mu \mathrm{M}$ mRNA, $3 \mu \mathrm{M}$ $\left[{ }^{35} \mathrm{~S}\right] \mathrm{fMet}-\mathrm{tRNA}{ }^{\mathrm{fMet}}$, and $3 \mu \mathrm{M}$ each of IF1, IF2, and IF3 in buffer B (50 mM Tris- $\mathrm{HCl} \mathrm{pH} \mathrm{7.5,} 70 \mathrm{mM} \mathrm{NH}_{4} \mathrm{Cl}, 30 \mathrm{mM} \mathrm{KCl}$, and 7 $\mathrm{mM} \mathrm{MgCl} 2$ ). The reaction mix was incubated at $37^{\circ} \mathrm{C}$ for $20 \mathrm{~min}$ and purified through a Sephacryl S200 (Sigma-Aldrich) column. The initiation complexes were then diluted to a final concentration of $0.2 \mu \mathrm{M}$ in buffer A. E. coli ternary complex mixture contained $0.1 \mu \mathrm{M}$ native E. coli Phe-tRNA ${ }^{\text {Phe }}$ or Tyr-tRNA ${ }^{\text {Phe }}$ and $5 \mu \mathrm{M}$ activated E. coli EF-Tu. The quench-flow experiment was done by rapidly mixing $15 \mu \mathrm{L}$ initiation complex and $15 \mu \mathrm{L}$ ternary complex at $25^{\circ} \mathrm{C}$, followed by quenching with $1 \mathrm{M} \mathrm{KOH}$ at desired time points on a KinTek quench-flow machine. Reaction products were incubated at $37^{\circ} \mathrm{C}$ for $30 \mathrm{~min}$ to hydrolyze peptidyl- and aminoacyl-tRNAs, and separated on glass-back silica TLC plates (AnalTech). The solvent used was 3:1:1 (V/V/ $\mathrm{V})$ butanol:acetic acid:water containing $50 \mathrm{mM} \beta$-mercaptoethanol. Spots were visualized by phosphorimaging and quantified using ImageQuant.

\section{Poly(U)-directed polyPhe and polyTyr synthesis}

The reaction mixture contained $5 \mathrm{mM}$ Tris- $\mathrm{HCl} \mathrm{pH} \mathrm{7.5,} 5 \mathrm{mM}$ $\mathrm{MgAc}_{2}, 20 \mathrm{mM} \mathrm{NH}_{4} \mathrm{Cl}, 1 \mathrm{mM}$ ATP, $30 \mu \mathrm{M}$ GTP, $30 \mathrm{mM} \beta-$ mercaptoethanol, $1 \mathrm{mM}$ DTT, $5 \mathrm{mM}$ PEP, $20 \mu \mathrm{g} / \mathrm{mL}$ PK, $200 \mathrm{nM}$ 70S ribosomes, $1 \mu \mathrm{M}$ E. coli EF-G, $5 \mu \mathrm{M}$ E. coli EF-Tu, $0.3 \mu \mathrm{g} / \mu \mathrm{L}$ poly(U) mRNA, and $1 \mu \mathrm{M}\left[{ }^{14} \mathrm{C}\right]$ Phe-tRNA ${ }^{\text {Phe }}$ or $\left[{ }^{3} \mathrm{H}\right]$ TyrtRNA $^{\text {Phe }}$ synthesized with native E. coli tRNA $^{\text {Phe }}$. Reaction was performed at $37^{\circ} \mathrm{C}$ and aliquots were spotted on $3 \mathrm{MM}$ discs presoaked with $10 \%$ TCA, washed twice in $5 \%$ TCA at $90^{\circ} \mathrm{C}$ for $10 \mathrm{~min}$ each, dried, and scintillation counted.

\section{ACKNOWLEDGMENTS}

We thank Dr. B. Kraal (Leiden University, Leiden, The Netherlands) and Dr. D. Tirrell (California Institute of Technology, Pasadena, CA) for strains and plasmids, and Dr. K. Fredrick for helpful discussions and materials. We also thank H. Roy and C. Hausmann for critical reading of the manuscript, and D. Qin and S. Shoji for materials. This work was supported by National Science Foundation Grant MCB-0344002.

Received June 18, 2007; accepted July 25, 2007.

\section{REFERENCES}

Ahel, I., Korencic, D., Ibba, M., and Söll, D. 2003. Trans-editing of mischarged tRNAs. Proc. Natl. Acad. Sci. 100: 15422-15427.

Ambrogelly, A., Palioura, S., and Söll, D. 2007. Natural expansion of the genetic code. Nat. Chem. Biol. 3: 29-35.

An, S. and Musier-Forsyth, K. 2005. Cys-tRNA ${ }^{\text {Pro }}$ editing by Haemophilus influenzae $\mathrm{YbaK}$ via a novel synthetase/YbaK/tRNA ternary complex. J. Biol. Chem. 280: 34465-34472.

Asahara, H. and Uhlenbeck, O.C. 2002. The tRNA specificity of Thermus thermophilus EF-Tu. Proc. Natl. Acad. Sci. 99: 3499-3504.

Asahara, H. and Uhlenbeck, O.C. 2005. Predicting the binding affinities of misacylated tRNAs for Thermus thermophilus EFTu.GTP. Biochemistry 44: 11254-11261.

Bacher, J.M., De Crécy-Lagard, V., and Schimmel, P.R. 2005. Inhibited cell growth and protein functional changes from an editing-defective tRNA synthetase. Proc. Natl. Acad. Sci. 102: 1697-1701.

Becker, H.D. and Kern, D. 1998. Thermus thermophilus: A link in evolution of the tRNA-dependent amino acid amidation pathways. Proc. Natl. Acad. Sci. 95: 12832-12837.

Beebe, K., Ribas De Pouplana, L., and Schimmel, P. 2003. Elucidation of tRNA-dependent editing by a class II tRNA synthetase and significance for cell viability. EMBO J. 22: 668-675.

Beebe, K., Merriman, E., Ribas De Pouplana, L., and Schimmel, P. 2004. A domain for editing by an archaebacterial tRNA synthetase. Proc. Natl. Acad. Sci. 101: 5958-5963.

Beuning, P.J. and Musier-Forsyth, K. 2000. Hydrolytic editing by a class II aminoacyl-tRNA synthetase. Proc. Natl. Acad. Sci. 97: 8916-8920.

Bhuta, A., Quiggle, K., Ott, T., Ringer, D., and Chladek, S. 1981. Stereochemical control of ribosomal peptidyltransferase reaction. Role of amino acid side-chain orientation of acceptor substrate. Biochemistry 20: 8-15.

Blanchard, S.C., Gonzalez, R.L., Kim, H.D., Chu, S., and Puglisi, J.D. 2004. tRNA selection and kinetic proofreading in translation. Nat. Struct. Mol. Biol. 11: 1008-1014.

Chapeville, F., Lipmann, F., von Ehrenstein, G., Weisblum, B., Ray Jr., W.J., and Benzer, S. 1962. On the role of soluble ribonucleic 
acid in coding for amino acids. Proc. Natl. Acad. Sci. 48: 10861092.

Cochella, L. and Green, R. 2005. An active role for tRNA in decoding beyond codon:anticodon pairing. Science 308: 1178-1180.

Dale, T. and Uhlenbeck, O.C. 2005a. Amino acid specificity in translation. Trends Biochem. Sci. 30: 659-665.

Dale, T. and Uhlenbeck, O.C. 2005b. Binding of misacylated tRNAs to the ribosomal A site. RNA 11: 1610-1615.

Dale, T., Sanderson, L.E., and Uhlenbeck, O.C. 2004. The affinity of elongation factor $\mathrm{Tu}$ for an aminoacyl-tRNA is modulated by the esterified amino acid. Biochemistry 43: 6159-6166.

Dock-Bregeon, A., Sankaranarayanan, R., Romby, P., Caillet, J., Springer, M., Rees, B., Francklyn, C.S., Ehresmann, C., and Moras, D. 2000. Transfer RNA-mediated editing in threonyl-tRNA synthetase. The class II solution to the double discrimination problem. Cell 103: 877-884.

Dock-Bregeon, A.C., Rees, B., Torres-Larios, A., Bey, G., Caillet, J., and Moras, D. 2004. Achieving error-free translation; the mechanism of proofreading of threonyl-tRNA synthetase at atomic resolution. Mol. Cell 16: 375-386.

Döring, V., Mootz, H.D., Nangle, L.A., Hendrickson, T.L., De CrécyLagard, V., Schimmel, P., and Marlière, P. 2001. Enlarging the amino acid set of Escherichia coli by infiltration of the valine coding pathway. Science 292: 501-504.

Fahlman, R.P., Dale, T., and Uhlenbeck, O.C. 2004. Uniform binding of aminoacylated transfer RNAs to the ribosomal A and P sites. Mol. Cell 16: 799-805.

Fredrick, K. and Noller, H.F. 2002. Accurate translocation of mRNA by the ribosome requires a peptidyl group or its analog on the tRNA moving into the 30S P site. Mol. Cell 9: 1125-1131.

Fukai, S., Nureki, O., Sekine, S., Shimada, A., Tao, J., Vassylyev, D.G., and Yokoyama, S. 2000. Structural basis for double-sieve discrimination of L-valine from L-isoleucine and L-threonine by the complex of tRNA ${ }^{\mathrm{Val}}$ and valyl-tRNA synthetase. Cell 103: 793-803.

Gromadski, K.B. and Rodnina, M.V. 2004a. Kinetic determinants of high-fidelity tRNA discrimination on the ribosome. Mol. Cell 13: 191-200.

Gromadski, K.B. and Rodnina, M.V. 2004b. Streptomycin interferes with conformational coupling between codon recognition and GTPase activation on the ribosome. Nat. Struct. Mol. Biol. 11: 316322.

Ibba, M. and Söll, D. 1999. Quality control mechanisms during translation. Science 286: 1893-1897.

Korencic, D., Ahel, I., Schelert, J., Sacher, M., Ruan, B., Stathopoulos, C., Blum, P., Ibba, M., and Söll, D. 2004. A freestanding proofreading domain is required for protein synthesis quality control in Archaea. Proc. Natl. Acad. Sci. 101: 1026010265.

LaRiviere, F.J., Wolfson, A.D., and Uhlenbeck, O.C. 2001. Uniform binding of aminoacyl-tRNAs to elongation factor Tu by thermodynamic compensation. Science 294: 165-168.

Lee, J.W., Beebe, K., Nangle, L.A., Jang, J., Longo-Guess, C.M., Cook, S.A., Davisson, M.T., Sundberg, J.P., Schimmel, P., and Ackerman, S.L. 2006. Editing-defective tRNA synthetase causes protein misfolding and neurodegeneration. Nature 443: 50-55.

Lin, S.X., Baltzinger, M., and Remy, P. 1984. Fast kinetic study of yeast phenylalanyl-tRNA synthetase: Role of tRNA ${ }^{\text {Phe }}$ in the discrimination between tyrosine and phenylalanine. Biochemistry 23: $4109-4116$.

Lincecum, T.L., Tukalo, M., Yaremchuk, A., Mursinna, R.S., Williams, A.M., Sproat, B.S., Van Den Eynde, W., Link, A., Van Calenbergh, S., Grøtli, M., et al. 2003. Structural and mechanistic basis of pre- and post-transfer editing by leucyl-tRNA synthetase. Mol. Cell 11: 951-963.

Ling, J., Roy, H., and Ibba, M. 2007. Mechanism of tRNA-dependent editing in translational quality control. Proc. Natl. Acad. Sci. 104: 72-77.
Nangle, L.A., De Crécy-Lagard, V., Döring, V., and Schimmel, P. 2002. Genetic code ambiguity. Cell viability related to the severity of editing defects in mutant tRNA synthetases. J. Biol. Chem. 277: $45729-45733$.

Nissen, P., Kjeldgaard, M., Thirup, S., Polekhina, G., Reshetnikova, L., Clark, B.F., and Nyborg, J. 1995. Crystal structure of the ternary complex of Phe-tRNA ${ }^{\text {Phe }}$, EF-Tu, and a GTP analog. Science 270: $1464-1472$.

Nureki, O., Vassylyev, D.G., Tateno, M., Shimada, A., Nakama, T., Fukai, S., Konno, M., Hendrickson, T.L., Schimmel, P., and Yokoyama, S. 1998. Enzyme structure with two catalytic sites for double-sieve selection of substrate. Science 280: 578-582.

Ogle, J.M., Murphy, F.V., Tarry, M.J., and Ramakrishnan, V. 2002. Selection of tRNA by the ribosome requires a transition from an open to a closed form. Cell 111: 721-732.

Pape, T., Wintermeyer, W., and Rodnina, M.V. 1998. Complete kinetic mechanism of elongation factor Tu-dependent binding of aminoacyl-tRNA to the A site of the E. coli ribosome. EMBO J. 17: 7490-7497.

Pape, T., Wintermeyer, W., and Rodnina, M. 1999. Induced fit in initial selection and proofreading of aminoacyl-tRNA on the ribosome. EMBO J. 18: 3800-3807.

Pape, T., Wintermeyer, W., and Rodnina, M.V. 2000. Conformational switch in the decoding region of $16 \mathrm{~S}$ rRNA during aminoacyltRNA selection on the ribosome. Nat. Struct. Biol. 7: 104-107.

Roy, H., Ling, J., Irnov, M., and Ibba, M. 2004. Post-transfer editing in vitro and in vivo by the $\beta$ subunit of phenylalanyl-tRNA synthetase. EMBO J. 23: 4639-4648.

Roy, H., Ling, J., Alfonzo, J., and Ibba, M. 2005. Loss of editing activity during the evolution of mitochondrial phenylalanyl-tRNA synthetase. J. Biol. Chem. 280: 38186-38192.

Roy, H., Becker, H.D., Mazauric, M.-H., and Kern, D. 2007. Structural elements defining elongation factor Tu mediated suppression of codon ambiguity. Nucleic Acids Res. 35: 3420-3430. doi: 10.1093/ nar/gkm211.

Schmeing, T.M., Huang, K.S., Strobel, S.A., and Steitz, T.A. 2005. An induced-fit mechanism to promote peptide bond formation and exclude hydrolysis of peptidyl-tRNA. Nature 438: 520-524.

Silvian, L.F., Wang, J., and Steitz, T.A. 1999. Insights into editing from an Ile-tRNA synthetase structure with tRNA ${ }^{\text {Ile }}$ and mupirocin. Science 285: 1074-1077.

Stanzel, M., Schon, A., and Sprinzl, M. 1994. Discrimination against misacylated tRNA by chloroplast elongation factor Tu. Eur. J. Biochem. 219: 435-439.

Starck, S.R., Qi, X., Olsen, B.N., and Roberts, R.W. 2003. The puromycin route to assess stereo- and regiochemical constraints on peptide bond formation in eukaryotic ribosomes. J. Am. Chem. Soc. 125: 8090-8091.

Vorstenbosch, E.L., Potapov, A.P., de Graaf, J.M., and Kraal, B. 2000. The effect of mutations in EF-Tu on its affinity for tRNA as measured by two novel and independent methods of general applicability. J. Biochem. Biophys. Methods 42: 1-14.

Wang, L., Xie, J., and Schultz, P.G. 2006. Expanding the genetic code. Annu. Rev. Biophys. Biomol. Struct. 35: 225-249.

Wolfson, A.D. and Uhlenbeck, O.C. 2002. Modulation of tRNA ${ }^{\text {Ala }}$ identity by inorganic pyrophosphatase. Proc. Natl. Acad. Sci. 99: 5965-5970.

Wong, F.C., Beuning, P.J., Silvers, C., and Musier-Forsyth, K. 2003. An isolated class II aminoacyl-tRNA synthetase insertion domain is functional in amino acid editing. J. Biol. Chem. 278: 5285752864.

Xie, J. and Schultz, P.G. 2006. A chemical toolkit for proteins-An expanded genetic code. Nat. Rev. Mol. Cell Biol. 7: 775-782.

Youngman, E.M., Brunelle, J.L., Kochaniak, A.B., and Green, R. 2004. The active site of the ribosome is composed of two layers of conserved nucleotides with distinct roles in peptide bond formation and peptide release. Cell 117: 589-599. 

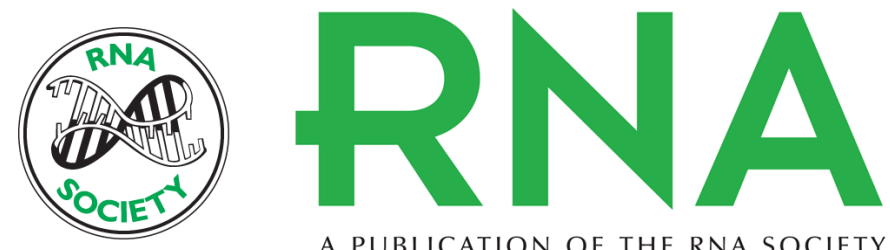

A PUBLICATION OF THE RNA SOCIETY

\section{Phenylalanyl-tRNA synthetase editing defects result in efficient mistranslation of phenylalanine codons as tyrosine}

Jiqiang Ling, Srujana S. Yadavalli and Michael Ibba

RNA 2007 13: 1881-1886 originally published online September 5, 2007

Access the most recent version at doi:10.1261/rna.684107

References This article cites 52 articles, 25 of which can be accessed free at:

http://rnajournal.cshlp.org/content/13/11/1881.full.html\#ref-list-1

License

Email Alerting Receive free email alerts when new articles cite this article - sign up in the box at the Service top right corner of the article or click here. 